\title{
KEMAMPUAN MEMBACA CEPAT SISWA KELAS XI SMA NEGERI 5 BANJARMASIN
}

\author{
Jumainah $^{1}$ \\ 1. Program Studi Pendidikan Bahasa Inggris \\ STKIP PGRI Banjarmasin \\ JumaiMainah@gmail.com (081351446515)
}

\begin{abstract}
ABSTRAK
Penelitian ini dilakukan untuk mendeskripsikan kemampuan siswa kelas sebelas dalam membaca cepat. Membaca cepat adalah memadukan (perpaduan) kemampuan motorik (gerakan mata) atau visual dengan kemampuan kognitif seseorang dalam membaca. Jadi, membaca cepat merupakan perpaduan antara kecepatan membaca dengan pemahaman isi bacaan. Metode yang digunakan dalam penelitian ini adalah metode deskriptif kuantitatif. Populasi penelitian ini adalah seluruh siswa kelas XI SMA Negeri 5 Banjarmasin yang terdiri dari program IPA 3(tiga) kelas A, B dan C begitu juga dengan kelas IPS 3(tiga) A, B dan $\mathrm{C}$ dengan total jumlah 217. Teknik pengambilan sampel yang digunakan adalah Cluster Random Sampling, teknik ini memunculkan kelas A IPA yang berjumlah 36 siswa dan kelas A IPS berjumlah 73 siswa. Instrumen yang digunakan dalam penelitian ini adalah tes, tes yang digunakan untuk mengambil data pada penelitian ini adalah tes kemampuan membaca cepat dan pemahaman teks bacaan. Hasil penelitian ini menunjukkan bahwa kemampuan membaca cepat siswa program IPA memiliki kualifikasi cukup dengan rata-rata 200,7742. Sedangkan kemampuan membaca cepat siswa program IPS memiliki kualifikasi kurang dengan rata-rata 145,3 . Kemampuan pemahaman isi bacaan siswa program IPA memiliki kualifikasi cukup dengan rata-rata 60\%. Sedangkan kemampuan pemahaman isi bacaan siswa program IPS memiliki kualifikasi kurang dengan rata-rata $50 \%$,
\end{abstract}

Kata kunci: kemampuan, membaca cepat

\section{A. Latar Belakang}

\section{PENDAHULUAN}

Perkembangan ilmu pengetahuan dan teknologi ditandai dengan banyaknya informasi yang bisa kita temui diberbagai media, baik media cetak maupun media elektronik. Agar bisa menyerap informasi yang ada di media cetak, dibutuhkan kemampuan membaca yang cukup bagi setiap orang. Ahmad (2011:15) mendefinisikan membaca sebagai suatu proses yang dilakukan dan digunakan oleh pembaca untuk memperoleh pesan yang hendak disampaikan oleh penulis melalui media kata-kata bahasa tulis (tulisan). Namun dari segi linguistik, membaca adalah suatu penyandian kembali dan pembacaan sandi (encoding and decoding process). 
Seseorang dikatakan mampu membaca bukan karena secara kebetulan atau didorong oleh inspirasi, tetapi karena hasil dari belajar. Membaca bukanlah kegiatan alamiah, tetapi kegiatan terstruktur yang mempunyai seperangkat komponen yang dikuasai secara pribadi dan bertahap, yang kemudian terintegrasi dan menjadi otomatis. Menurut Yunus (2007:1.5) kemampuan membaca adalah kemampuan berbahasa secara aktif untuk menyerap informasi atau pesan yang disampaikan melalui media tulis. Disebut aktif karena membaca bukan sekedar memahami lambang tulis, tapi juga membangun makna, memahami, menerima, menolak, membandingkan, dan meyakinkan isi tulisan.

Dalam proses pembelajaran biasanya seorang pembelajar merasakan nikmatnya membaca, bukan hanya sebagai peristiwa pemecahan kode, tetapi juga sebagai penerimaan pengetahuan dan kebahagiaan. Orang akan tampil tenang dan matang karena memiliki berbagai pengalaman tambahan seperti ia bisa menikmati fiksi dan non fiksi yang dibacanya. Ditinjau dari segi anak, ada kemungkinan mereka menemukan kegembiraan, tetapi hal ini sangat bergantung pada asuhan dan arahan para orang tua dan guru.

Membaca adalah kegiatan atau aktivitas yang rumit atau kompleks, bergantung pada keterampilan berbahasa pelajar dan tingkat penalarannya (Nababan, 1993: 164). Di sisi lain, Suyatmi berpendapat bahwa membaca bukan merupakan kegiatan yang menyuarakan lambang-lambang tertulis, tetapi mempersoalkan apakah kalimat atau kata-kata yang dilisankan itu dipahami atau tidak (2000:4). Sejalan dengan beberapa pengertian di atas Burhan berpendapat membaca dalam arti sesungguhnya ialah perbuatan yang dilaksanakan berdasarkan kerjasama atas beberapa keterampilan, yaitu mengamati, memahami, dan memikirkan (Suyatmi, 2000:5).

Berpijak dari pengertian di atas, dapat disimpulkan bahwa membaca adalah kegiatan untuk memahami ide atau gagasan yang tersurat maupun tersirat di dalam suatu bacaan yang melibatkan kerjasama beberapa komponen keterampilan berbahasa: mengamati, memahami, dan memikirkan.

Tanpa kemampuan membaca yang cukup, seseorang akan lambat dalam memahami informasi yang terdapat dalam suatu bacaan. Koermin (1997: 112) mengemukakan bahwa semua informasi dengan mudah dapat kita ketahui lewat membaca yang memadai, tetapi hal itu tidak menjamin dia memahami dengan cepat. Mengingat begitu pentingnya membaca cepat, maka membaca perlu diajarkan kepada setiap generasi. Upaya untuk mengembangkan dan meningkatkan kemampuan membaca cepat, di Indonesia juga diajarkan di SD, SMP, dan SMA.

Dalam era yang maha cepat seperti sekarang, dimana tanpa kita kehendaki tuntutan kehidupan meningkat, membaca tak lagi boleh hanya sebagai pembawa kenikmatan, tetapi juga sebagai alat pencapai percepatan itu sendiri. Artinya orang wajib mengejar semua informasi. Ia harus memiliki keterampilan mengumpulkan data dengan cepat sekaligus benar. Dan disini membaca cepat menjadi utama.

Muchlishoh (1992: 153) mengatakan membaca cepat yaitu jenis membaca yang diberikan dengan tujuan agar para siswa dalam waktu singkat dapat membaca secara lancar, serta dapat memahami isinya. Sedangkan Hernowo Ed. 2003 mengatakan membaca cepat adalah keterampilan membaca sekilas dengan mengkondisikan otak bekerja lebih cepat sehingga konsentrasi akan lebih membaik secara otomatis. Dalam hal ini kita dituntut untuk memusatkan 
konsentrasi kita dalam proses membaca guna mengefisiensikan waktu yang kita miliki dan juga energi yang kita keluarkan juga akan relatif lebih banyak. Membaca cepat merupakan perpaduan antara kecepatan membaca dengan kecepatan memahami isi bacaan.

Tidak ada orang yang dapat membaca cepat karena bakat. Oleh karena itu harus dipahami bahwa membaca cepat bukanlah melulu cepat memecah kode dan segera menyelesaikan sebuah buku. Membaca cepat adalah kegiatan membaca untuk memahami isinya. Bersamaan dengan hal tersebut di atas Supriyadi (1995: 127) menyatakan "keterampilan membaca yang sesungguhnya bukan hanya sekedar kemampuan menyuarakan lambang tertulis dengan sebaik-baiknya namun lebih jauh adalah kemampuan memahami dari apa yang tertulis dengan tepat dan cepat".

Pada umumnya pembelajaran membaca cepat kurang mendapatkan perhatian sehingga banyak ditinggalkan oleh pengajar. Hal ini disebabkan para guru beranggapan bahwa materi membaca cepat tidak perlu diajarkan karena tidak di-EBTANAS-kan atau di-UAN-kan.Selain itu, pembelajaran membaca cepat membutuhkan waktu yang relatif lama dengan prosedur yang relatif rumit.

Standar kompetensi mata pelajaran Bahasa dan sastra Indonesia berorientasi pada hakikat pembelajaran bahasa.Belajar bahasa adalah belajar berkomunikasi dan belajar sastra adalah belajar menghargai manusia dan nilainilai kemanusiaannya. Oleh karena itu, pembelajaran Bahasa Indonesia diarahkan untuk meningkatkan kemampuan siswa untuk berkomunikasi dalam bahasa Indonesia, baik secara lisan maupun tertulis serta menimbulkan penghargaan terhadap hasil cipta menusia Indonesia (Depdiknas, 2003).

Standar kompetensi membaca dalam pelajaran Bahasa Indonesia adalah siswa mampu membaca dan memahami berbagai jenis wacana, baik secara tersurat maupun tersirat untuk berbagai tujuan. Lebih khusus lagi, standar kompetensi dasar membaca cepat dalam Kurikulum 2004 diberlakukan secara berjenjang. Untuk kelas $\mathrm{X}$, standar kompetensi membaca cepat meliputi: (1) membaca cepat berbagai teks nonsastra $250 \mathrm{kpm}$ (kata permenit), (2) membaca ekstentif teks nonsastra dari berbagai sumber. Untuk kelas XI, standar kompetensi membaca cepat adalah membaca cepat $300 \mathrm{kpm}$, sedangkan untuk kelas XII, standar kompetensi membaca cepat adalah membaca dengan kecepatan 300 s.d. $350 \mathrm{kpm}$ dengan panjang bacaan 900 s.d. $1050 \mathrm{kata}$, dan pemahaman atas isi bacaan masing-masing 70\%. Jadi, ada dua kemampuan yang harus dimiliki oleh para siswa dalam membaca cepat ini, yaitu kemampuan membaca dengan kecepatan kata permenit dan memahami isi bacaan minimal $70 \%$.

Melihat pentingnya peran membaca sebagaimana telah diuraikan diatas, selayaknya pembelajaran membaca khususnya membaca cepat juga mendapatkan perhatian yang sangat besar dari pelaksana pendidikan, terutama guru. Dalam kegiatan membaca cepat di SMA biasanya siswa disuruh membaca, kemudian diberi pertanyaaan atas bacaan. Guru jarang sekali mengukur seberapa besar kemampuan membaca cepat dan persentase pemahaman isi yang dicapai siswanya. Guru beranggapan bahwa yang penting setelah membaca siswa dapat menjawab pertanyaan yang tersedia. Ketika siswa mampu menjawab dengan serentak, guru beranggapan semua siswa sudah tahu apa yang dibaca dan guru merasa lega dengan jawaban tersebut dan guru tidak berkeinginan untuk mengetahui secara pasti kemampuan membaca setiap siswa. Pembelajaran lebih 
mengutamakan penyelesaian bahan ajar secara lebih cepat, tanpa memperhatikan kompetensi membaca cepat.

Dalam penelitian Kemampuan Membaca Cepat Siswa Kelas XI SMA Negeri 5 Banjarmasin, peneliti sengaja memilih siswa SMA sebagai objek penelitian karena SMA merupakan lembaga pendidikan yang mempersiapkan para siswanya untuk menuju ke perguruan tinggi. Sebagaimana diketahui di perguruan tinggi mahasiswa dituntut untuk menguasai bahan bacaan yang tentunya lebih banyak daripada bahan bacaan yang diperuntukkan bagi peserta didik pada lembaga-lembaga pendidikan di bawahnya. Berdasarkan hasil survey yang dilakukan oleh peneliti kemampuan membaca cepat dan pemahaman isi bacaan di kelas XI SMA Negeri 5 Banjarmasin masih tergolong rendah, hal ini peneliti ketahui dari hasil wawancara guru mata pelajaran Bahasa Indonesia di sekolah tersebut

Sekolah Menengah Atas Negeri 5 Banjarmasin untuk kelas XI terdiri atas dua jurusan, jurusan IPA dan jurusan IPS; keduanya akan menjadi sampel pada penelitian ini.

Penelitian ini hanya memilih SMA Negeri dengan alasan:

1. Sekolah Negeri memiliki fasilitas yang memadai dibandingkan dengan sekolah Swasta

2. Kebanyakan tenaga pengajarnya adalah PNS. Dengan demikian, diharapkan kualiatasnya lebih baik karna mereka banyak mendapatkan pembinaan dan latihan-latihan sebagai tenaga pengajar.

Sepengetahuan peneliti, berdasarkan studi pendahuluan diperputsakaanperpustakaan perguruan tinggi yang ada di Banjarmasin, penelitian yang khusus mengangkat tentang bagaimana kemampuan membaca cepat pada tingkat SMA belum pernah ada, terutama di Sekolah Menengah Atas Negeri 5 kelas XI Banjarmasin. Adapun penelitian yang pernah dilakukan berdasarkan studi pendahuluan tersebut adalah kemampuan membaca cepat pada tingkat SD, seperti di SDN Tatah Belayung Baru kecamatan Kertyak Hanyar kabupaten Banjar yang dilakukan oleh Amruddin (2011) dan SDN Waringin Kencana kecamatan Wanaraya kebupaten Barito Kuala oleh Lestari (2011). Oleh karena itu, peneliti memberanikan diri untuk mengadakan penelitian tentang bagaimana kemampuan membaca cepat siswa kelas XI SMA Negeri 5 Banjarmasin. Selain itu pula peneliti mau membuktikan kebenaran dari informasi yang peneliti dapat bahwa kemampuan membaca cepat siswa kelas XI SMA Negeri 5 Banjarmasin masih rendah sebagai mana dijelaskan diatas.

Berangkat dari uarian diatas, peneliti tertarik untuk mengadakan penelitian tentang kemampuan membaca cepat dengan judul Kemampuan Membaca Cepat Siswa Kelas XI SMA Negeri 5 Banjarmasin.

\section{B. Rumusan Masalah}

Membaca cepat adalah jenis membaca yang menarik untuk diteliti. Karena membaca cepat dan pemahaman isi adalah jenis membaca yang sering bermasalah.

Adapun permasalahan yang dirumuskan sebagai berikut.

1. Bagaimana kemampuan membaca cepat siswa kelas XI program IPA dan IPS SMA Negeri 5 Banjarmasin? 
2. Bagaimana kemampuan pemahaman isi bacaan siswa kelas XI program IPA dan IPS SMA Negeri 5 Banjarmasin?

\section{Tujuan Penelitian}

Tujuan penelitian ini adalah untuk memperoleh gambaran atau deskriptif tentang tingkat kemampuan siswa kelas XI SMA Negeri 5 Banjarmasin dalam membaca cepat dan memahami isi bacaan, dan secara khusus penelitian ini bertujuan sebagai berikut.

1. Untuk mendapatkan gambaran tentang kemampuan membaca cepat siswa kelas XI program IPA dan IPS SMA Negeri 5 Banjarmasin.

2. Untuk mendapatkan gambaran tentang kemampuan pemahaman isi bacaan siswa kelas XI program IPA dan IPS SMA Negeri 5 Banjarmasin.

\section{KAJIAN TEORI}

\section{A. Membaca dan Proses Membaca}

Pengertian membaca pada dasarnya adalah proses memaknai simbol-simbol tertulis untuk memperoleh makna atau proses menangkap pikiran dan perasaan orang lain dengan perantaraan tulisan (Purwanto dan Ngalim,1997:27. Hudgson (1960:43) mengatakan membaca adalah suatu proses yang dilakukan serta dipergunakan oleh pembaca untuk memperoleh pesan yang hendak disampaikan penulis melalui kata-kata dalam bahasa tulis. Suatu proses yang menuntut pembaca agar dapat memahami kelompok kata yang tertulis merupakan suatu kesatuan dan terlihat dalam suatu pandangan sekilas, dan makna kata-kata itu dapat diketahui secara tepat. Apabila hal ini dapat terpenuhi, pesan yang tersurat dan yang tersirat dapat dipahami sehingga proses membaca sudah terlaksana dengan baik.

Membaca berdasarkan kecepatan dan tujuannya dapat dibedakan menjadi lima yaitu membaca intensif, membaca kritis, membaca cepat,membaca indah, dan membaca teknik.

\section{a. Membaca Intensif.}

Membaca intensif adalah membaca yang dilakukan secara cermat dan hati-hati dengan tujuan untuk memahami seluruh isi teks (buku) secara mendalam dan detail. Dengan demikian, jenis membaca intensif ini sangat cocok untuk seseorang yang tujuan membacanya adalah untuk memperoleh informasi atau pengetahuan yang sangat detail dan komprehensif dari sebuah buku.

\section{b. Membaca Kritis}

Membaca kritis adalah membaca dengan melihat motif penulis dan menilainya. Sehingga, pembaca tidak sekadar membaca, namun juga berpikir tentang masalah yang dibahas oleh penulis buku tersebut. Dengan demikian, membaca kritis adalah membaca aktif. 


\section{c. Membaca Cepat}

Membaca cepat adalah suatu kegiatan membaca yang menitikberatkan pada kecepatan memahami isi bacaan dengan cepat dan tepat dalam waktu yang relatif singkat. Membaca cepat dilakukan apabila akan mengambil gagasan pokok dan garis besarnya saja. Dalam hal ini, waktu harus diperhatikan dan dimanfaatkan sebaik-baiknya. Jenis membaca cepat inilah, yang menjadi fokus dari penelitian ini namun hanya mengukur kemampuan kecepatan baca siswa.

\section{d. Membaca Indah}

Membaca indah adalah kegiatan membaca yang menitikberatkan pada aspek keindahan teks bacaan. Biasanya, membaca jenis ini sangat tepat digunakan untuk membaca teks-teks sastra. Dalam membaca karya sastra dengan gaya membaca indah ini, pembaca hendaknya menjatuhkan alur suaranya pada gagasan-gagasan, sebagaimana layaknya orang berbicara. Gerak dan mimik harus sejalan dengan gagasan pokok yang terkandung dalam teks sastra tersebur. Dengan demikian, membaca indah adalah teknik membaca yang menekankan pada sisi keindahan dari suatu karya sastra.

\section{e. Membaca Teknik}

Membaca teknik adalah suatu kegiatan membaca dengan menggunakan suara. Singkatnya,membaca teknik adalah membaca nyaring. Maksudnya, ketika membaca teks harus mengiringinya dengan suara yang nyaring. Biasanya, jenis membaca ini sering digunakan oleh guru saat mengajar siswanya di kelas. Guru mendikte siswa dengan membaca nyaring.

\section{B. Membaca Cepat}

Untuk meningkatkan kemampuan membaca, salah satu hal yang perlu kita upayakan peningkatannya ialah kecepatan membaca, membaca cepat adalah keterampilan membaca sekilas dengan mengkondisikan otak bekerja lebih cepat sehingga konsentrasi akan lebih menarik secara otomatis (Tampobolon, 1987: 36). Dalam hal ini kita dituntut untuk memusatkan konsentrasi kita dalam proses membaca guna mengefisienkan waktu yang kita miliki dan juga energi yang kita keluarkan juga akan relatif lebih banyak. Membaca cepat termasuk aktivitas yang melibatkan kerja otak dan gerak mata. Dengan demikian, kegiatan ini adalah sebuah kegiatan yang sangat kompleks karena melibatkan kerja fisik dan mental.

Membaca cepat adalah fokus dalam penelitian ini, membaca cepat adalah kecakapan membaca dan memahami teks dalam tingkatan tinggi. Rata-rata orang dengan pendidikan setingkat sekolah tinggi membaca sekitar 300 kata permenit, berarti bahan itu tidaklah bersifat teknis. Di sisi lain, pembaca cepat dapat membaca lebih dari 1000 kata per menit. Pengukuran membaca cepat baru sangat berarti bila digabungkan dengan informasi seberapa tinggi pemahaman teks itu oleh pembacanya. Diketahui bahwa orang dengan kemampuan membaca cepat yang lebih tinggi juga memiliki pemahaman yang lebih tinggi. 
Nurhadi ( 1987:31-32) menyatakan "membaca cepat dan efektif ialah jenis membaca yang mengutamakan kecepatan, dengan tidak meninggalkan pemahaman terhadap aspek bacaannya"

Muchlisoh (1992:149) mengatakan bahwa membaca cepat bukan berarti jenis membaca yang ingin memperoleh jumlah bacaan atau halaman yang banyak dalam waktu yang singkat. Saleh Abbas (2006:108) menyatakan "membaca cepat adalah membaca sekejap mata, selayang pandang. Tujuannya adalah dalam waktu yang singkat pembaca memperoleh informasi secara cepat dan tepat".

Dari beberapa pendapat di atas dapat disimpulkan bahwa dalam membaca cepat diperlukan konsentrasi yang lebih ketika membaca dan juga diperlukan perpaduan kemampuan motorik dengan kemampuan kognitif serta diperlukan waktu yang relatif singkat guna memperoleh informasi yang ada dalam bacaan baik yang tersirat maupun tersurat. Pada saat-saat tertentu pembaca dituntut untuk bersifat fleksibel di dalam menghadapi dan menyiasati becaannya. Kadangkadang diperlukan waktu yang relatif lebih lama untuk memahami sesuatu, tetapi adakalanya pembaca memerlukan waktu yang relatif singkat. Dengan pandangan sekilas saja, pembaca sudah dapat menangkap isi sebuah bacaan.

Memiliki kemampuan membaca cepat berarti mampu menguasai isi bacaan dengan waktu yang relatif singkat dan mampu mengungguli kekuatan fisik yang dimiliki oleh manusia. Hampir semua jenis keterampilan membaca dapat diperbaiki dan dilatih dengan jalan latihan. Jika faktor-faktor yang mempengaruhi keterampilan membaca tersebut dikuasai dengan sebaik-baiknya, maka kemampuan membaca pun pasti membaik. Dengan demikian, waktu yang digunakan untuk membaca akan bertambah singkat. Seseorang dikatakan membaca cepat jika pemahamannya terhadap bacaan sangat tinggi dibanding waktu yang tersedia. Apabila waktu yang diperlukan dalam membaca semakin sedikit, sedangkan tingkat pemahamannya sangat tinggi, maka dapat dikatakan bahwa kecepatan baca orang tersebut semakin meningkat. Namun fokus pembahasan dalam penelitian ini adalah tingkat kemampuan kecepatan baca siswa.

\section{A. Metode}

\section{METODE PENELITIAN}

Metode yang digunakan dalam penelitian ini adalah metode deskriptifdalam bentuk survey. Digunakannya metode deskriftif ini dimaksudkan untuk memberikan gambaran tentang kecepatan membaca siswa kelas XI SMA Negeri 5 Banjarmasin.

Penelitian ini menggunakan pendekatan kuantitatif, dimana peneliti akan bekerja dengan angka-angka dan informasi-informasi data dengan menggunakan analisa data statistik. Populasi adalah keseluruhan subjek dalam penelitian. Berdasarkan lokasi penelitian yang dipilih, populasi yang ditetapkan untuk penelitian ini adalah seluruh siswa kelas XI Sekolah Menengah Atas Negeri 5 Banjarmasin tahun ajaran 2010/2011. Pada sekolah ini siswa kelas XI memiliki jurusan IPA dan IPS, setiap program memiliki beberapa kelas, untuk program IPA 
terdiri dari 3 kelas yaitu kelas a, b dan c. untuk program IPS juga memiliki 3 kelas yaitu kelas a, b dan c.

Dalam penelitian ini peneliti menggunakan teknik Cluster Random Sampling. Hasil pengambilan dengan teknik ini secara random memunculkan kelas A untuk IPA dan kelas A untuk IPS, dengan jumlah siswa 36 orang program IPA ruang A dan 37 orang program IPS ruang A. Jadi jumlah sampel seluruhnya adalah 73 siswa.

\section{B. Data, Sumber Data dan Teknik Pengumpulan Data}

Sumber data dari penelitian ini adalah siswa kelas XI IPA dan IPS SMAN

5 Banjarmasin. data penelitian ini dapat dikelompokan menjadi empat jenis data.

a. Data kemampuan membaca cepat siswa kelas XI program IPA dan IPS SMA Negeri 5 Banjarmasin.

b. Data kemampuan pemahaman isi bacaan siswa kelas XI program IPA da IPS SMA Negeri 5 Banjarmasin.

Teknik pengumpulan data yang dipergunakan dalam penelitian ini adalah tes, observasi dan wawancara

\section{HASIL PENELITIAN DAN PEMBAHASAN}

Kecepatan membaca menuntut dua kemampuan utama, yaitu kemampuan visual yang berkenaan dengan kecepatan rata-rata membaca dan kemampuan kognisi yang berkenaan dengan kemampuan memahami isi bacaan. Pembaca yang memiliki kedua komponen tersebut dalam kegiatan membaca berarti dapat mencapai kecepatan efektif membaca yang sesuai dengan kriteria yang ditentukan.

Kemampuan membaca cepat siswa program IPA memiliki kualifikasi cukup dengan rata-rata 200,77 kpm dan program IPS memiliki kualifikasi kurang dengan rata-rata $145,3 \mathrm{kpm}$. Sedangkan kemampuan pemahaman isi bacaan siswa program IPA memiliki kualifikasi cukup dengan rata-rata $60 \%$ dan program IPS memiliki kualifikasi kurang dengan rata-rata 50\%. Berikut tabel-tabel data persentase kemampuan membaca cepat dan pemahaman isi bacaan siswa kelas XI program IPA dan IPS SMAN 5 Banjarmasin.

Tabel 1

Data Kemampuan Membaca cepat siswa kelas XI SMA Negeri 5 Banjarmasin Program IPA

\begin{tabular}{|c|c|c|c|c|}
\hline No & Kualifikasi & Rentang Skor & Frekuensi & Persentase \\
\hline 1 & Mampu & $300-399$ & 6 & $19 \%$ \\
2 & Cukup & $200-299$ & 11 & $35 \%$ \\
3 & Kurang & $100-199$ & 14 & $46 \%$ \\
\hline \multicolumn{2}{|c|}{ Total } & 31 & $100 \%$ \\
\hline \multicolumn{2}{|c|}{ Rata-rata } & \multicolumn{2}{c|}{200,7742} \\
\hline
\end{tabular}

Berdasarkan tabel di atas, siswa program IPA memiliki nilai rata-rata 200,77 kpm dalam membaca cepat, 6 siswa yang mampu dengan persentase 19\%, 11 siswa yang cukup dengan persentase 35\%, 14 siswa yang kurang dengan persentase $46 \%$. Dengan demikian, kemampuan membaca cepat siswa kelas XI SMA Negeri 5 Banjarmasin program IPA tergolong cukup. 
Tabel 2

Data Kemampuan Membaca cepat siswa kelas XI SMA Negeri 5 Banjarmasin Program IPS

\begin{tabular}{|c|c|c|c|c|}
\hline No & Kulifikasi & Rentang Skor & Frekuensi & Persentase \\
\hline 1 & Mampu & 300-399 & - & - \\
\hline 2 & Cukup & 200-299 & 6 & $18 \%$ \\
\hline 3 & Kurang & $100-199$ & 27 & $82 \%$ \\
\hline \multicolumn{3}{|c|}{ Total } & 33 & $100 \%$ \\
\hline \multicolumn{3}{|c|}{ Rata-rata } & \multicolumn{2}{|c|}{145,3} \\
\hline
\end{tabular}

Berdasarkan tabel diatas, siswa program IPS memiliki nilai rata-rata 145,3 $\mathrm{kpm}$ dalam membaca cepat, tidak ada siswa yang mampu dengan persentase $0 \%$, 6 siswa yang cukup dengan persentase 18\%, 27 siswa yang kurang dengan persentase $82 \%$. Dengan demikian, kemampuan membaca cepat siswa kelas XI SMA Negeri 5 Banjarmasin program IPS tergolong masih rendah.

Tabel 3

Data Kemampuan Pemahaman Isi Bacaan siswa kelas XI SMA Negeri 5 Banjarmasin Program IPA

\begin{tabular}{|c|c|c|c|c|}
\hline No & Kualifikasi & Rentang Skor & Frekuensi & Persentase \\
\hline 1 & Mampu & $75-100$ & 6 & $19 \%$ \\
2 & Cukup & $51-74$ & 16 & $52 \%$ \\
3 & Kurang & $0-50$ & 9 & $29 \%$ \\
\hline \multicolumn{3}{|c|}{ Total } & 31 & $100 \%$ \\
\hline \multicolumn{2}{|c|}{ Rata-rata } \\
\hline
\end{tabular}

Berdasarkan tabel di atas, siswa program IPA memiliki nilai rata-rata $60 \%$ dalam pemahaman isi bacaan, 6 siswa yang mampu dengan persentase 19\%, 16 siswa yang cukup dengan persentase $52 \%$, dan 9 siswa yang kurang dengan perrsentase $29 \%$. Dengan demikian, kemampuan pemahaman isi bacaan siswa kelas XI SMA Negeri 5 Banjarmasin program IPA tergolong cukup.

\section{Tabel 4}

Data Kemampuan Pemahaman Isi Bacaan siswa kelas XI SMA Negeri 5 Banjarmasin Program IPS

\begin{tabular}{|c|c|c|c|c|}
\hline No & Kualifikasi & Rentang Skor & Frekuensi & Persentase \\
\hline 1 & Mampu & $75-100$ & 1 & $3 \%$ \\
2 & Cukup & $51-74$ & 9 & $27 \%$ \\
3 & Kurang & $0-50$ & 22 & $70 \%$ \\
\hline \multicolumn{3}{|c|}{ Total } & 33 & $100 \%$ \\
\hline \multicolumn{3}{|c|}{ Rata-rata } & \multicolumn{2}{c|}{$50 \%$} \\
\hline
\end{tabular}

Berdasarkan tabel di atas, siswa program IPS memiliki nilai rata-rata 50\% dalam pemahaman isi bacaan, yang mampu hanya 1 orang dengan persentase $3 \%$, yang cukup 9 orang dengan persentase 27\%, dan yang kurang 23 orang dengan persentase $70 \%$. Dengan demikian, kemampuan pemahaman isi bacaan siswa kelas XI SMA Negeri 5 Banjarmasin program IPS tergolong masih rendah

Dari tabel-tabel diatas dapat diketahui berbedaan kemampuan membaca cepat dan pemahaman isi bacaan antara siswa kelas XI program IPA dan program IPS. Perbedaan kemampuan membaca cepat dan pemahaman isi bacaan antara 
program IPA dan IPS adalah sebagai berikut.Kemampuan membaca cepat siswa program IPA dikategorikan cukup dengan memiliki rata-rata $200,77 \mathrm{kpm}$ dan program IPS dikategorikan kurang dengan memiliki rata-rata 145,3 kpm.Kemampuan pemahaman isi bacaan siswa program IPA dikategorikan cukup dengan rata-rata $60 \%$, sedangkan untuk program IPS dikategorikan kurang dengan rata-rata $50 \%$.

\section{A. Simpulan}

\section{PENUTUP}

Berdasarkan penelitian tentang kemampuan membaca cepat yang sudah dilaksanakan di SMA Negeri 5 Banjarmasin, dapat diperoleh hasil sebagai berikut:

1. Kemampuan membaca cepat siswa program IPA memiliki kualifikasi cukup dengan rata-rata 200,7742, 6 siswa yang mampu dengan persentase $19 \%, 11$ siswa yang cukup dengan persentase 35\%, 14 siswa yang kurang dengan persentase $46 \%$. Sedangkan kemampuan membaca cepat siswa program IPS memiliki kualifikasi kurang dengan rata-rata 145,3, tidak ada siswa yang mampu dengan persentase $0 \%, 6$ siswa yang cukup dengan persentase $18 \%$, dan yang kurang 27 orang dengan persentase $82 \%$.

2. Kemampuan pemahaman isi bacaan siswa program IPA memiliki kualifikasi cukup dengan rata-rata 60\%, 6 siswa yang mampu dengan persentase 19\%, 16 siswa yang cukup dengan persentase 52\%, dan 9 siswa yang kurang dengan persentase $29 \%$. Sedangkan kemampuan pemahaman isi bacaan siswa program IPS memiliki kualifikasi kurang dengan rata-rata $50 \%, 1$ siswa yang mampu dengan persentase 3\%, 9 siswa yang cukup dengan persentase $27 \%$, dan 23 siswa yang kurang dengan persentase $70 \%$.

\section{B. Saran}

Peniliti ingin memberikan beberapa saran berdasarkan hasil dari penelitian lakukan, saran tersebut adalah sebagai berikut:

1. bagi peneliti selanjutnya, diharapkan meneliti dengan sample yang lebih besar dan menggunakan lebih dari satu variable dan pendalaman pada analisis data (infensial statistik).

2. Bagi siswa yang memiliki kemampuan rendah pada kemampuan membaca khususnya membaca cepat agar lebih sering berlatih dan belajar.

3. Bagi guru mata pelajaran, Mengingat membaca merupakan salah satu keterampilan dalam menangkap pikiran orang lain, hendaknya guru SMAN dan khususnya guru SMA Negeri 5 Banjarmasin kelas XI dapat melatih dan mengawasi para murid dalam pembelajaran membaca khususnya membaca cepat.

4. Bagi kepala sekolah selaku pembina, dapat memberikan bimbingan kepada guru kelas dan guru yang lai dalam pembelajaran Bahasa Indonesia. 


\section{DAFTAR PUSTAKA}

Arikunto, Suharsimi. 1998. Prosedur Penelitian. Renika Cipta. Jakarta

Ahmad, Listiyanto. 2010. Speed Reading; Teknik dan Metode Membaca Cepat, Jogjakarta: A+plus Book.

Aizid, Rizem. 2011. Bisa Baca Secepat Kilat (Super Quick Reading). Jogjakarta. Buku Biru

Burn, P.C., Roe, B.D., and Ross, E.P. 1996. Teaching Reading in Today's Elementary School. Boston: Houghton Mifflin Company.

Departemen Pendidikan Nasional. 2003. Kurikulum 2004, Standar Kompetensi, Mata Pelajaran Bahasa Indonesia, SMA dan MA. Jakarta: Depdiknas.

Departemen Pendidikan Nasional. 2003. Kurikulum 2004 SMA, Pedoman Khusus Pengembangan Silabus dan Penilaian Mata Pelajaran bahasa dan sastra Indonesia. Jakarta: Depdiknas, Ditjen Dikdasmen.

Haryadi. 2006. Retorika Membaca, Model, Metode dan Teknik. Semarang: Rumah Indonesia.

Hernomo (Ed.). 2003. Quantum Reading. Bandung: MLC.

Koermen, Imam. 1997. Pembelajaran Keterampilan Membaca.Jakarta : Depdikbud

Milan, D.K. 1988. Improving Reading Skills. Newyork: Random Hause.

Nababan. S. U. S. 1993. Metodologi Pengajaran Bahasa. Jakarta: Gramedia.

Nurhadi.1987. Membaca Cepat dan Efektif. Bandung: CV Sinar Baru.

Pamungkas, Daud: 2002. Membaca. Banjarmasin PBSID UNLAM. Banjarmasin

Suyatmi. 2000. Membaca I. Surakarta: UNS Press.

Suyatmi. 1984. Keterampilan Membaca. Surakarta: UNS Press

Suyitno dan Purwadi. 2000. Dasar-Dasar Komposisi. Surakarta: UNS Press

Singh, B. 1979. Improving Speed and Comprehension in Reading. Forum, 17: 4243.

Soedarso. 2001. Speed Reading. Sistem Membaca Cepat dan Efektif. Jakarta: PT Gramedia.

Tampubolon, DP. 1990. Kemampuan Membaca, Teknik Membaca Efektif dan Efisien. Bandung: Angkasa.

Tampubolon, DP. (1985). Membaca: Pengertian dan Implikasinya Dalam Analisis Pendidikan. Nopember 1985 Jakarta : Depdiknas

Tarigan, Djago, dkk 1986. Teknik Pengajaran Keterampilan Berbahasa. Bandung: Angkasa Bandung.

Tarigan, H.G (1985). Membaca Sebagai Suatu Keterampilan Berbahasa. Bandung: Penerbit Angkasa.

Yunus, Mohammad, 2007. Membaca dan Strategy. Jakarta : Universitas Terbuka 